\title{
REACTION IN LEPROSY PRECIPITATED BY SMALLPOX VACCINATION
}

\author{
By S. G. Browne, M.D., F.R.C.P., F.R.C.S., D.T.M. \\ Leprosy Service Research Unit, Uzuakoli, Eastern Nigeria \\ and Esther M. Davis, M.B., B.CH., B.A.O., D.R.C.O.G. \\ Qua Iboe Mission Leprosy Settlement, Ekpene Obom, Eastern Nigeria. \\ Smallpox vaccination, it has long been recognized, may precipi- \\ tate erythema nodosum leprosum and lepra reaction in a proportion \\ of lepromatous patients, and the risk of developing such a reaction \\ must sometimes be weighed nicely against the risk of contracting \\ smallpox. The observations recorded in this paper, drawn from a \\ recent experience of smallpox, may help doctors whose leprosy \\ patients are faced with the threat of the disease.
}

\section{The outbreak of smallpox.}

After a fortnight's visit to his village, a patient under treatment for tuberculoid leprosy returned to the Ekpene Obom Leprosy Settlement, Eastern Nigeria, suffering from mild smallpox. Although he remained in the settlement for only a few hours, within a fortnight 4 patients ( 1 lepromatous, 1 borderline and 2 tuberculoid), who had been in contact with him, succumbed to the disease.

All the settlement patients were thereupon vaccinated (on 4 th and 5th February, 1962), but 6 of these (all with lepromatous disease) developed smallpox in mid-February: 4 of them had adequate scars of primary vaccination, and 2 had been successfully vaccinated for the first time. A fortnight later, a further 3 patients fell ill with smallpox ( 1 lepromatous, 1 borderline and 1 tuberculoid); 2 of these had been revaccinated and the other had been primarily vaccinated with success, in February.

Except in one fatal case (whose vaccinal state was not known), the disease was generally mild, whether the victims had been revaccinated (10) or vaccinated for the first time when the risk of smallpox was apparent (3). To judge from the symptoms and the low mortality, the severity of the disease was probably attenuated by the vaccination.

\section{Susceptibility to smallpox infection}

Although the vaccinal state of patients suffering from the different forms of leprosy was similar and the exposure to smallpox infection was probably uniform, susceptibility to the disease appears to have varied roughly with the numbers of $M$. leprae in skin and nasal mucosa, as the accompanying table indicates. 


\begin{tabular}{l|r|r|r|r|r|r|r|r}
\hline & & & \multicolumn{3}{|c|}{ Vaccinations, Fehruary, 1962} & \multicolumn{2}{|c}{ Smallpox } \\
$\begin{array}{l}\text { Form of } \\
\text { leprosy }\end{array}$ & No. & $\%$ & Total & \multicolumn{2}{|c|}{$\begin{array}{c}\text { Revaccinations } \\
\text { No. }\end{array}$} & $\begin{array}{c}\text { Primary } \\
\text { vaccina- } \\
\text { tions }\end{array}$ & No. & $\begin{array}{c}\text { Attack } \\
\text { rate } \\
\%\end{array}$ \\
\hline $\begin{array}{l}\text { Lepromatous } \\
\text { Borderline }\end{array}$ & 64 & 25 & 63 & 38 & 60 & 25 & 8 & 13 \\
$\begin{array}{l}\text { Tuberculoid } \\
\text { Indeterminate }\end{array}$ & 140 & 14 & 34 & 18 & 53 & 16 & 2 & 6 \\
& 19 & 7 & 19 & 90 & 65 & 48 & 4 & 3 \\
\hline & 259 & 100 & 254 & 157 & 62 & 97 & 14 & 5 \\
\hline
\end{tabular}

\section{Lepra reaction in the vaccinated}

No patient suffering from non-lepromatous leprosy developed any local or focal reactional condition following vaccination. Of the 63 lepromatous patients vaccinated or revaccinated in February, 1962, 12 developed reaction of some degree: 5 of them were among the 14 patients (including 8 lepromatous) who developed smallpox, the remaining 7 being among the 56 lepromatous patients who did not develop smallpox. Two of the 12 patients (who were suffering from persistent severe reaction when vaccinated), developed smallpox and became worse.

To complete the picture, it should be added that 3 patients with tuberculoid leprosy and 3 with borderline leprosy who had had recurrent attacks of neuritis in the past, with swelling of the skin lesions, experienced no recrudescence after vaccination. A lepromatous patient who had suffered from psychosis four years previously had no recurrence after being vaccinated.

\section{Susceptibility to reaction following vaccination}

Of 16 patients with lepromatous leprosy who had previously had one or more reactional episodes, 9 experienced no reaction after being vaccinated, but vaccination precipitated a recurrence of reaction in the remaining 7 .

The appearance of reaction seemed to bear no relation to the clinical severity of the vaccinia as judged by the size of the vesicle and the systemic disturbance, nor to the precise level of the Bacterial Index (either on admission or before vaccination), except that only 3 patients experiencing reaction had an index below $1 \cdot 0$.

\section{Clinical features}

There were no remarkable features in the clinical varieties of reaction observed, and nothing to differentiate them from reaction as it occurs in this district in lepromatous patients either in the course of treatment or spontaneously. In most of the 12 patients affected, the temperature was raised for a variable period and generalized malaise was marked: 6 had erythema nodosum leprosum; 4 had acute 
polyneuritis; in 3, new lepromatous lesions appeared in the skin; 1 had epistaxis.

In 9 cases, the reaction was mild, and seemed to respond to rest, suppression of anti-leprosy treatment and sedatives, though spontaneous resolution cannot be ruled out.

In the remaining 3 patients, however, 2 of them being in reaction when smallpox showed itself, the reactions failed to respond to these non-specific measures and were sufficiently severe to require corticosteroid therapy.

\section{Subsequent progress}

Ten of the 12 patients who experienced reaction in some form recovered completely from the episode within a short time, and no clinical deterioration of the leprosy condition occurred. Bacteriological examination of skin smears revealed no interruption in the progressive fall of the Bacterial Index, no difference being discerned between them and the patients who had no reaction.

The condition of the two patients already under treatment for severe reaction when vaccinated continued to be serious. My mid-May one of them was well enough to be discharged from hospital, prednisolone having controlled the symptoms. He, however, died a month later of an intercurrent disease unconnected with leprosy or with lepra reaction. The other patient who had experienced recurrent severé reactions since 1960, was admitted to hospital early in March, 1962, with high temperature, acute purulent degeneration of many recent nodules, and severe polyneuritis. He lapsed into sudden unconsciousness after four weeks of corticosteroid and supporting therapy, and died in a few minutes.

\section{Summary}

When exposed to smallpox, patients suffering from lepromatous leprosy seem to be more susceptible to smallpox than those suffering from non-lepromatous leprosy, and those who succumb to smallpox tend to suffer from lepra reaction.

Lepromatous patients run a real risk of developing a reactional condition as the result of smallpox vaccination, especially if they have had reaction previously. This reaction is in general mild and transient, leaving no sequelae and not interrupting clinical or bacteriological progress, but patients already in reaction when vaccinated undergo a deterioration.

\section{Acknowledgements}

Our thanks are due to Dr. S. E. Onwu, M.v.O., O.B.E., Director of Medical Services and Permanent Secretary, Ministry of Health, Eastern Nigeria, for permission to publish this article. 